DOI https://doi.org/10.18551/rjoas.2018-09.06

\title{
MUTUAL FUND PERFORMANCE IN INDONESIA
}

\author{
Risamena Vencysisca Jeane*, Wiagustini Luh Putu \\ University of Udayana, Bali, Indonesia \\ *E-mail: sisca267@yahoo.co.id
}

\begin{abstract}
The purpose of this study was to explain the performance of equity funds in Indonesia for the 2013-2017. The research subjects were equity mutual funds listed on the Indonesia Stock Exchange (IDX) with a number of samples taken as many as 73 equity mutual fund products, with purposive sampling method. Data analysis method uses two average difference test analysis techniques (Independent Sample t-test). The results show that the performance of equity funds has not been able to outperform market performance during the observation period. Comparison between the performance of equity funds and market performance shows that there are no significant differences. There is no difference in investments through mutual funds of shares or ordinary shares in generating risk adjusted returns. The practical implication that can be given from the findings of this study is that this study can be used as information for investors in choosing investment instruments in the Indonesian capital market. In accordance with the results of the study, investors can invest in the form of ordinary shares or equity funds because it produces the same rate of return adjusted risk.
\end{abstract}

\section{KEY WORDS}

Mutual funds, performance, market, investment.

Mutual funds according to Capital Market law number 8 of 1995 article 1, paragraph (27) "Mutual funds are a container used to raise funds from the public for further investment in securities portfolios by Investment Managers". Mutual fund products are sold in the form of investment units. The investment unit is stated as the number of investors' ownership in the mutual fund. NAB (Net Asset Value) is the amount of funds managed in a mutual fund. NAB is obtained by calculating the total market value of portfolio securities minus liabilities, then divided by the number of shares outstanding (Jones, 2012). The return on mutual funds is obtained based on the difference between the NAV per unit of participation when making a purchase with the NAV per unit of participation when reselling.

Equity mutual funds are mutual funds with an investment portfolio of at least $80 \%$ which are securities in the form of shares (Wijaya, 2013). Mutual funds generally use an active strategy approach. Investment managers actively conduct market research and buy assets to form a mutual fund portfolio. The purpose of investment managers doing market research and asset change is to outperform benchmarks in order to get a greater return (Baker et.al, 2016). Changes in assets that form a mutual fund portfolio have an impact on the performance of equity funds. Periodic evaluation of mutual fund performance is one of the important factors in choosing a mutual fund that can provide optimal results.

The benchmark that can be used to compare the rate of return on a mutual fund is the market rate of return. Market returns in Indonesia are often used as a benchmark, namely the Composite Stock Price Index. The performance condition of mutual funds is seen from the rate of return compared to the $\mathrm{JCl}$ during 2017.

Research on the performance of mutual funds has been carried out in several countries. Research conducted by Ashraf and Sharma (2014) on the performance of mutual funds in India shows that most mutual funds outperform market benchmarks. This research was supported by Panda and Moharana (2014), Goyal (2015), Choudary and Chawla (2016), Agarwal and Mirza (2017), Yalavatti and Bheemanagouda (2017). Research on the performance of mutual funds in Croatia shows that mutual funds are able to outperform market performance in Novakovic (2015), Curkovic and Kristo (2017). The performance of 
mutual funds in China shows better performance than the benchmark in research conducted by Kiymaz (2015). Research by Ömer Faruk Tan (2015) also shows that South African equity funds have a good performance. Other studies such as Ravi et al. (2013), Abdullah and Nur (2014), Qamruzzaman (2014), Lemenskho and Rejnus (2015), Srinidhi et. al (2016) showed different results, that the performance of mutual funds showed a performance that was not better than the performance of the benchmark.

\section{LITERATURE REVIEW}

Investment is the current commitment to a certain amount of funds held in a certain period of time to gain profits in the future (Reilly and Brown, 2012). According Jogiyanto (2013), investment is a delay in current consumption to be included in productive assets for a certain period of time. Jones (2014) defines investment as a broad activity and leads to deposits in physical form such as gold or buildings, or in the form of letters, bonds, shares or mutual funds.

The approach commonly used in managing portfolios is Markowitz's approach. Markowitz's approach bases the portfolio management framework based on the principle of returns and risks. Markowitz also introduced the concept of diversification which aims to reduce portfolio risk without sacrificing expected returns (Wiksuana, 2017). Portfolio management recognizes the concept of risk reduction as a result of adding securities to the portfolio. The more number of shares that make up a portfolio, the greater the benefits of risk reduction (Tandelilin, 2010). The concept of risk minimization is in line with the law of large numbers in statistics. The concept states that the greater the sample size, the more likely the sample average is to approach the expected value in the population (Jones, 2012). The more the amount of securities entered into the portfolio, the greater the risk reduction benefits obtained. Risk minimization can occur due to variations in income levels between securities in a given period, so combining various securities in a portfolio causes portfolio income levels to become more stable and reduce risk (Wiksuana 2017).

Passive portfolio strategy is a strategy where investors tend to be passive in investing in stocks and only base the movement of stocks on the movement of the market index. Investors are not active in seeking information or buying and selling shares that can produce abnormal returns. Investors with a passive strategy, believe that the market price that occurs is a price that reflects the intrinsic value of the stock. The strategy that belongs to the passive portfolio strategy is the buy and hold strategy and the indexing strategy. Active portfolio strategy is a strategy where investors tend to be active in finding information, buying and selling shares, following the time and movement of shares, as well as various other active actions to get abnormal returns. There are two approaches to stock analysis, namely a fundamental analysis approach and a technical analysis approach. Fundamental approach, analyzing a stock based on company data and reports. Technical approach, analyzing a stock by looking for patterns of stock price movements to estimate its movement in the future. The strategies included in the active portfolio strategy are stock selection strategies, sector rotation strategies and price momentum strategies.

Definition of mutual funds according to the Capital Market Law Number 8 of 1995 Article 1, paragraph (27): "Mutual funds are a place to raise funds from the investor community which will then be invested in securities portfolios by the Investment Manager". Mutual funds come from the words 'mutual' and 'funds'. Mutual means maintaining or maintaining funds means money so that mutual funds can be interpreted as a collection of money that is guarded by certain parties to make a profit. As for other definitions, where mutual funds are a collection of funds obtained from investors, then managed by investment managers (Sekhar, 2017). Mutual funds are like a basket in which there are various types of stocks owned by an investment manager. The shares contained therein will vary between one mutual fund and another. The selection of stocks depends on the decision of the investment manager of the mutual fund manager.

One important factor in investment decisions is to assess portfolio performance. Portfolio performance provides information about the funds that have been invested. 
According to Tandelilin (2010), portfolio performance evaluation is related to 2 things, namely whether portfolio return is able to provide a return that is greater than portfolio return which is used as a benchmark and whether the return obtained is in accordance with the level of risk that must be borne. There are 3 methods of measuring portfolio performance based on the concept of return and risk. These three measures are known as risk-adjusted returns because they combine return and risk in a calculation (Tandelilin, 2010).

An efficient market is defined as a market where the price of all securities fully reflects all available information (Jones, 2012). The price of securities in an efficient market reflects the information available so as to provide a rate of return that is consistent with the level of risk. Relevant new information enters the market and relates to assets, resulting in the information being used in the analysis and interpretation of the value of the assets concerned. The result is a possible shift to the new equilibrium price. The equilibrium price will change when other new information enters the market. The market reacts quickly and accurately to form a new equilibrium price that fully reflects the information available. Such conditions are called efficient markets.

Hypotheses. Portfolio performance evaluation is related to 2 things, whether portfolio return is able to provide a return that is greater than portfolio return which is used as a benchmark and whether the return obtained is in accordance with the level of risk.

Research on India equity funds performance by Ashraf and Sharma (2014) shows that mean of equity funds return is higher than the average market return. Goyal (2015), Choudary and Chawla (2016) also found results that the mean of mutual funds return was higher than benchmark returns. Other research on the performance of mutual funds in China by Kiymaz (2015) shows that overall mutual funds in China have better performance than their benchmarks.

Based on the description of the theory and the results of previous studies, the hypothesis proposed in this research is:

$\mathrm{H}_{1}$ : There are significant differences between the performance of equity funds and market performance.

\section{METHODS OF RESEARCH}

This research includes quantitative descriptive research because this study aims to look for the performance of equity funds. This study wants to find out performance of equity funds in the Indonesia Stock Exchange (IDX). Variable in this research is performance of equity funds $\left(\mathrm{T}_{\mathrm{RD}}\right)$, which is calculated using the Treynor index, which is one of the riskadjusted return measures.

$$
\mathrm{T}_{\mathrm{RD}}=\frac{\mathrm{R}_{R D}-\mathrm{R}_{\mathrm{RF}}}{\beta_{\mathrm{RD}}}
$$

Where:

$\mathrm{T}_{\mathrm{RD}}=$ Treynor measures per equity funds product;

$R_{R D}=$ mean of equity funds return in t-period;

$\mathrm{R}_{\mathrm{RF}}=$ mean of risk free rate return in t-period;

$\beta_{\mathrm{RD}}=$ equation of linear regression (risk).

The results of the calculation of the performance of equity funds using the Treynor will be compared to market performance, to see whether the performance of equity funds is better or worse than market performance. This study also aims to see whether the performance of equity funds has a significant difference with market performance. This research was conducted using historical data on Net Asset Value (NAV) of equity funds on the IDX.

The population used in this study is all equity funds listed on the Stock Exchange in the period 2013-2017 as many as 216 equity funds. The method of determining the sample in this study is the purposive sampling method that is by selecting a sample with certain criteria. The criteria used are equity funds that are sampled as conventional non-mutual fund 
mutual funds. Islamic mutual funds do not solely take into account high returns. Sharia mutual fund management involves the process of cleaning non-halal income. This research focuses on finding a high rate of return with the lowest possible risk, so that only the conventional equity funds are calculated. The samples obtained were 73 samples.

Test the hypothesis by testing the normality first. This test is conducted to find out whether the data comes from a population that is normally distributed. Testing normality using the Kolmogorov Smirnov (K-S) test. After that hypothesis testing is done to see the significance of differences in the performance of equity funds using the two average difference test (independent T-test).

$$
\mathrm{t}=\frac{X 1-X 2}{\sqrt{\frac{(n 1-1) S 1^{2}+(n 1-1) S 2^{2}\left(\frac{1}{n 1}+\frac{1}{n 2}\right)}{n 1+n 2-2}}}
$$

Where:

$\mathrm{X} 1$ = average performance of equity funds (Treynor);

$\mathrm{X} 2$ = average market performance;

$\mathrm{S} 1$ = standard deviation of the performance of equity funds;

S2 = standard deviation of market performance;

$\mathrm{n} 1$ = number of sample performance of equity funds;

$\mathrm{n} 2$ = total sample market performance.

\section{RESULTS OF STUDY}

Results of Calculation of Market Returns. The calculation of mutual fund return in this study uses the mutual fund return formula described in the operational definition. The data used to calculate mutual fund return is the annual NAV of 73 mutual fund samples for the period 2013 to 2017.

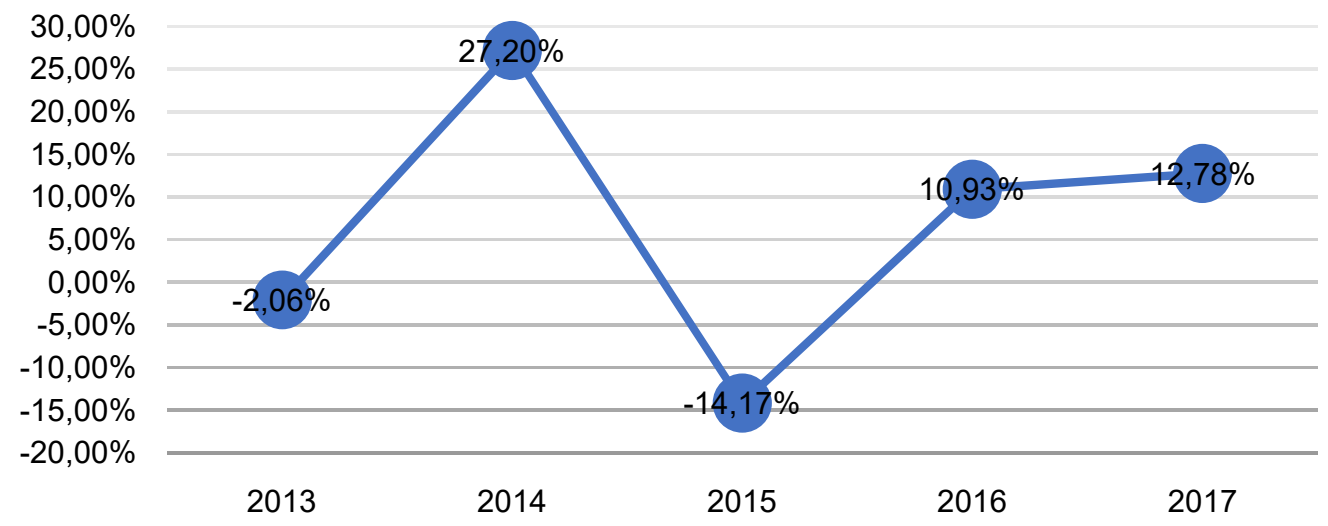

Figure 2 - Mean Return Equity Fund Per Year

Return on equity funds in 2013 showed that $70 \%$ of equity funds had negative returns, while the other $30 \%$ had positive returns. This period's equity funds produced an average return of $-0.0206401 \%$. Return on equity funds in 2014 shows that almost all equity funds have a positive return. The equity fund for the period of 2014 resulted in an average return of $0.271969831 \%$. The opposite happened in 2015 , all mutual funds have negative returns. The equity funds for the 2015 period resulted in an average return of $0.141704062 \%$.Returns on equity funds in 2016 and 2017 showed $95 \%$ and $93 \%$ of equity funds had positive returns. The equity fund for the period of 2016 resulted in an average return of $0.109324565 \%$, while the 2017 mutual fund period was able to generate a return of $0.127786557 \%$.

Results of Calculation of Market Returns. Market return is a market rate of return that uses data from the Composite Stock Price Index (CSPI). Market return calculation is done as a benchmark for the performance of equity funds. Calculation of market return in this study 
uses annual CSPI data during the study period. The results of the calculation of market returns during the study period indicate a fluctuating return. Market return in 2013 showed a negative return of $-0.00984783 \%$. The market return in 2014 showed a positive return of $0.222913089 \%$. Market return in 2015 showed a negative return of $-0.121282844 \%$. Market return in 2016 shows a positive return of $0.153211795 \%$. The market return in 2017 shows a positive return of $0.199924632 \%$.

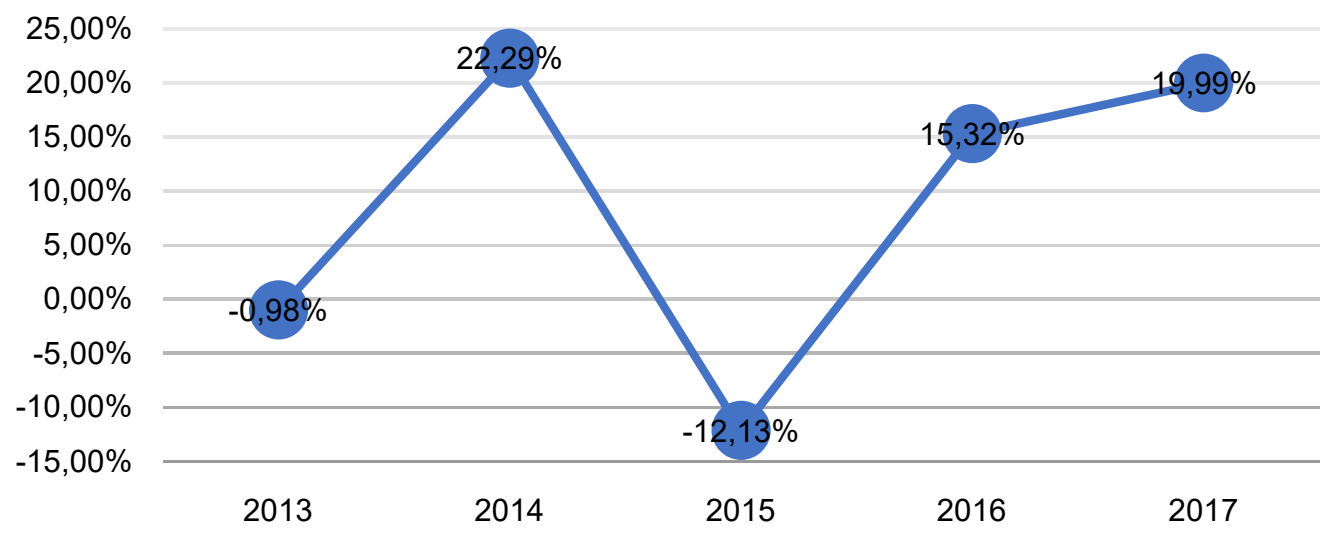

Figure 2 - Return Market per Year

Risk-free Return Calculation Results. Risk-free returns are assumed to be at interest rates for Bank Indonesia Certificates (SBI). The calculation of risk-free return in this study uses the average annual SBI interest rate during the study period. Following is the result of risk-free return calculation.

Table 1 - Risk Free Return

\begin{tabular}{|c|c|}
\hline Year & Risk Free Return \\
\hline 2013 & $6,48 \%$ \\
\hline 2014 & $7,54 \%$ \\
\hline 2015 & $7,52 \%$ \\
\hline 2016 & $6,00 \%$ \\
\hline 2017 & $4,56 \%$ \\
\hline
\end{tabular}

Primary Data, 2018.

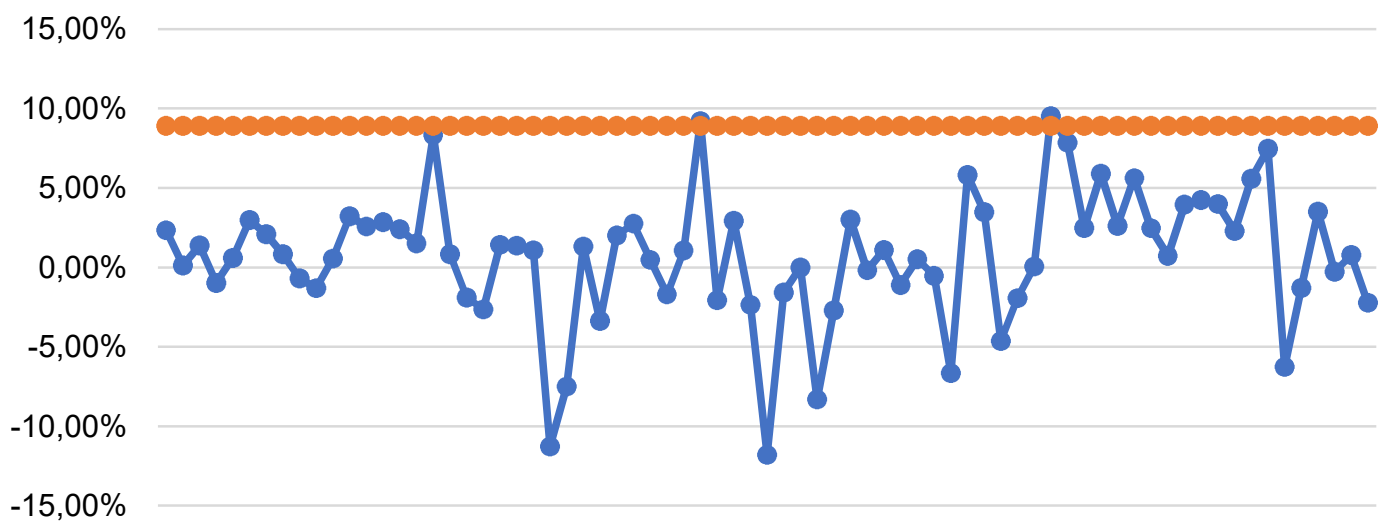

$\longrightarrow$ Mean of Equity Funds Treynor $\quad-$ Mean of Market Performance

Figure 3 - Comparison Mean of Equity Fund with Mean of Market Return Period 2013-2017

Beta Calculation Results. Beta calculation is obtained by regressing between return on equity funds and market returns. Beta is a measure of the sensitivity of return on equity 
funds to market changes. Beta calculation in this study uses Microsoft Excel program with a formula $(=\operatorname{SLOPE}(y, x))$, where $y$ is a mutual fund return and $x$ is a market return. The higher the beta, the higher the potential risk that can occur. Beta calculations are conducted per sample in equity funds.

Performance Calculation Results using the Treynor Method. Comparison of the average performance of equity funds with the average market return is shown in Figure 3.

The results of performance calculations during the study period indicate that there are no equity funds that consistently outperform market returns. The Treynor ratio in 2013 showed that 5 equity funds had a positive Treynor ratio and 68 equity funds with a negative Treynor ratio. Comparison of the performance of equity funds with market returns shows that there are 5 equity funds that have a performance above market performance (outperform). The Treynor ratio in 2014 shows that 72 equity funds have a positive Treynor ratio and 1 equity mutual fund with a negative Treynor ratio. Comparison of the performance of equity funds with market performance shows that 66 equity funds have performance above market performance (outperform).

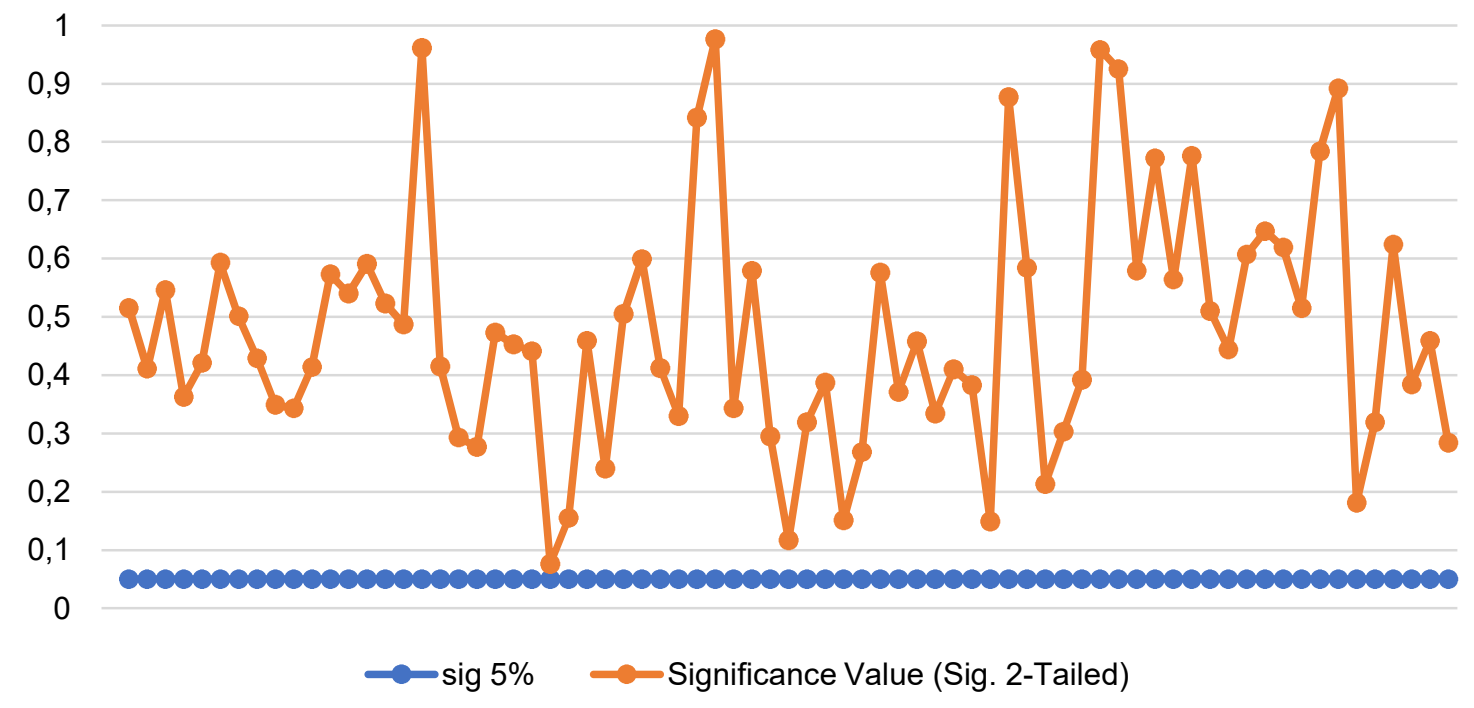

Figure 4 - Significance Difference Testing between Equity Funds Performance and Market Performance

The Treynor ratio in 2015 shows that 1 equity fund has a positive Treynor ratio and 72 equity funds with a negative Treynor ratio. Comparison of the performance of equity funds with market performance shows that 1 equity fund has a performance above market performance (outperform). The Treynor ratio in 2016 shows that 68 equity funds have a positive Treynor ratio and 5 equity funds with a negative Treynor ratio. Comparison of the performance of equity funds with market performance shows as many as 45 equity funds that have performance above market performance (outperform). The Treynor ratio in 2017 shows that as many as 64 equity funds have a positive Treynor ratio and 9 equity funds with a negative Treynor ratio. Comparison of the performance of equity funds with market performance shows as many as 55 equity funds that have performance above market performance (outperform).

The results of hypothesis testing using independent sample t-test showed a significance value above 0.05 , which mean performance of equity funds and market performance that there are no significant differences. There is no significant difference between the performance of equity funds and market performance, indicating that the risk adjusted return of equity funds is the same as the rate of return of market. This is shows that there is no abnormal return. Investments through conventional stocks or equity funds will provide the same return. 


\section{CONCLUSION AND SUGGESTIONS}

The performance of equity funds in Indonesia in this study shows that the performance of equity funds has not been able to outperform market performance consistently during the observation period. Comparison between the performance of equity funds and market performance shows that there are no significant differences. There is no difference in investments through mutual funds of shares or ordinary shares in generating risk adjusted returns. Investors can invest in the form of ordinary shares or equity funds because it produces the same rate of return adjusted risk. Investors who choose to invest through mutual funds can choose a mutual fund that has a mean performance above the market mean return. The limitations in this study are the assessment of the performance of equity funds based on Treynor performance calculations. For further researchers to add other factors in assessing the performance of equity funds such as assessing the ability of investment managers through market timing ability, composition of investment portfolios, analyzing the influence of AUM (asset under management) on the performance of equity funds.

\section{REFERENCES}

1. Abdullah, Ahmad Ridhuwan dan Nur Adiana Hiau Abdullah. 2014. Lipper's Rating and the Performance of Unit Trust in Malaysia. Emerald Studies in Economics and Finance. Vol. 32, Issue.1, pp.322-339.

2. Agarwal, Shivangi dan Nawazish Mirza. 2017. A Study On The Risk-Adjusted Performance of Mutual Funds Industry in India. Review of Innovation and Competitiveness Journal, Vol.3, Issue 1, pp.75-94.

3. Ashraf, Syed Husain dan Sharma Dhanraj. 2014. Performance Evaluation of Indian Equity Mutual Funds against Established Benchmarks Index. International Journal of Accounting Research, Vol 2. Issue 1.

4. Baker, H. Kent. Greg Filbeck dan Halil Kiymaz. 2016. Mutual Funds and ExchangeTraded Funds: Building Blocks to Wealth. New York: Oxford University Press.

5. Choudhary,Dr Vikas dan Chawla Preeti Sehgal. 2016. Performance Evaluation of Mutual Funds: A Study of Selected Large Cap Mutual Funds in India. Anvesha The Journal of Management, Vol.9, No.3.

6. Curkovic, Marko dan Kristo Jaksa. 2017. Performance Measurement of UCITS Investment Funds in Croatia. UTMS Journal of Economics, Vol.8, No.1, pp. 11-18.

7. Goyal, Dr.M.M. 2015. Performance Evaluation of Top 10 Mutual Funds in India. Indian Journal of Commerce \& Management Studies, Vol.6, Issue 1.

8. Jogiyanto, Hartono. 2013. Teori Portofolio dan Analisis Investasi. Edisi ke-8. Yogyakarta: BPFE UGM.

9. Jones, Charles P. 2012. Investments Analysis and Management. New York: John Wiley \& Sons, Inc.

10. Jones, Charles P. 2014. Investments Analysis and Management, $7^{\text {th }}$ Edition. New York: John Wiley \& Sons, Inc

11. Kiymaz, Halil. 2015. A performance evaluation of Chinese mutual funds. International Journal of Emerging Markets, Vol.10, No.4, pp.820-836.

12. Lemeshko,Oleksandra dan Rejnus Oldrich. 2015. Performance evaluation of equity mutual funds in countries with emerging economies: Evidence from BRIC, CEE, SEA and MENA regions. Procedia Economics and Finance, pp.476-486

13. Novakovic, Drazen. 2015. Evaluation of the Financial Performance of Pension Funds in Croatia. Ekonomski Vjesnik Econviews, pp. 199-212.

14. Omer, Faruk Tan. 2015. Mutual Fund Performance: Evidence from South Africa. Emerging Markets Journal, Vol.5, No.2.

15. Panda, Brahmadev dan Dr.Samson Moharana. 2014. Equity Mid-cap Mutual Funds: Risk and Return Analysis, Anvesha The Journal of Management, Vol.7, No.3. 
16. Qamruzzaman. 2014. Comparative Study on Performance Evaluation of Mutual Fund Schemes in Bangladesh: An Analysis of Monthly Returns.Journal of Business Studies Quarterly. Vol.5, No.4.

17. Ravi, Lonkani. Theeralak Satjawathee dan Kandiah Jegasothy. 2013. Selectivity and Market Timing Performance in a Developing Country's Fund Industry: Thai Equity Funds Case. Journal of Applied Finance \& Banking, vol. 3, no. 2, pp 89-108.

18. Reilly, Frank K dan Keith C. Brown. 2012. Investment Analysis \& Portfolio Management. Ohio: South-Western Cengange Learning.

19. Sekhar, Satya G.V. 2017. The Management of Mutual Funds. India: Palgrave Macmillan.

20. Srinidhi, Kanuri. Robert W. McLeod dan D.K Malhotra. 2016. An Empirical Examination of the Performance of Commodity Mutual Funds. The Journal of Wealth Management Spring, Vol.18, No.4, pp 90-106.

21. Tandelilin, Eduardus. 2010. Portofolio dan Investasi. Yogyakarta: Kanisius.

22. Undang-undang Republik Indonesia. 1995. Undang-undang Pasar Modal No.8 Tahun 1995 tentang Reksa Dana. Jakarta

23. Wijaya, Ryan Filbert. 2013. Menjadi Kaya \& Terencana dengan Reksa Dana. Jakarta: Elex Media Komputindo.

24. Wiksuana, I Gusti Bagus. 2017. Manajemen Portofolio Saham. Denpasar: PT. Mabhakti

25. Yalavatti, Prakash dan Bheemanagouda. 2017. A Study on the Performance of Large Cap Equity Mutual Funds in India. IUP Journal of Financial Risk Management. Vol.14, Issue 4, pp 30-44. 